\title{
Rec.: Ivana Vidović-Bolt, Životinjski svijet u hrvatskoj i poljskoj frazeologiji I. Hrvatska sveučilišna naklada, Zagreb 2011, 209 ss.
}

Monografia Životinjski svijet u hrvatskoj i poljskoj frazeologiji, której autorką jest Ivana Vidović-Bolt, ukazała się w grudniu 2011 r., wydana przez wydawnictwo Uniwersytetu w Zagrzebiu - Hrvatska sveučilišna naklada. Ivana Vidović Bolt jest chorwacką polonistką, pracującą w Katedrze Języka i Literatury Polskiej Uniwersytetu w Zagrzebiu, bardzo zaangażowaną w pracę naukową, dydaktyczną i popularyzatorską języka, kultury i literatury polskiej w Chorwacji, o czym świadczą Jej prace naukowe, podręczniki uniwersyteckie a także przekłady ze współczesnej literatury polskiej. Specjalizacja językoznawcza i zainteresowania translatorskie znalazły bogaty oddźwięk w pracach Autorki, związanych z problematyką frazeologiczną, wielu artykułach, a przede wszystkim dysertacji doktorskiej : Frazemi sa zoonimskom sastavnicom u poljskom i hrvatskom jeziku, obronionej w 2004 r. na Uniwersytecie w Zagrzebiu.

Prezentowana monografia I. Vidović-Bolt jest owocem rzetelnej i zapewne długotrwałej pracy naukowo-badawczej, polegającej w pierwszej kolejności na ekscerpcji materiału słownikowego $\mathrm{z}$ wielu słowników frazeologicznych języka polskiego i chorwackiego, słowników języka ogólnego, a także tematycznych: symboli, mitów. Autorka korzysta w swej pracy z prawie wszystkich słowników frazeologicznych języka polskiego, od słownika S. Skorupki począwszy, skończywszy na ostatnio wydanym: Wielkim słowniku frazeologicznym $P W N z$ przysłowiami (A. Kłosińska, A. Sobol, E. Stankiewicz) z 2010 r., co jest wysiłkiem godnym podziwu. 
Monografia I. Vidović-Bolt dotyczy obszernego i bogatego materiału frazeologicznego, jakim są frazeologizmy zoonimiczne, czyli takie, które zawierają w swym składzie nazwę zwierzęcia lub formę pochodną od niej. Autorka monografii zawęża dodatkowo analizowaną grupę do wyrażeń zawierających nazwę zwierzęcia domowego. Jest to zabieg jak najbardziej celowy, gdyż grupa frazeologizmów zoonimicznych, jak stwierdza I. Vidović, jest jedną z najliczniejszych grup, obok frazeologii somatycznej. Ponadto, inna jest rola, znaczenie, miejsce zwierząt domowych, a inna zwierząt dzikich, w życiu społecznym, kulturowym człowieka, co skutkuje też rozmaitą pozycją, konotacjami semantycznymi w języku, choć pokazanie takich paraleli byłoby zapewne ciekawym zabiegiem. Jest to jednakże temat na kolejną monografię, która być może powstanie, czego zapowiedzią zdaje się być enigmatyczny $\mathrm{nr}$ I, pojawiający się w tytule pracy, co pozwala mieć nadzieję na kontynuację tematyki porównawczo-zoonimicznej, lub może jakiejś innej kategorii tematycznej w obrębie frazeologii (niestety, $\mathrm{w}$ pracy nie ma na ten temat bliższych informacji).

Analizie poddano łącznie 614 frazeologizmów (323 chorwackie i 318 polskich) zawierających nazwę zwierzęcia domowego. Autorka już we wstępie zaznacza, że nie są to wszystkie jednostki frazeologiczne tej kategorii, gdyż celem jej pracy nie jest stworzenie spisu, słownika, a opis tych formacji pod wieloma aspektami: strukturalnym, syntaktycznym, semantycznym. Bierze pod uwage frazeologizmy u užem smislu (wg klasyfikacji chorwackiej - ustalone związki frazeologiczne, które uległy całkowitej lub znacznej desemantyzacji), o trzech typach strukturalnych: fonetska riječ, sveza riječi, frazemska rečenica. Zgodnie z tendencjami panującymi obecnie w chorwackiej frazeologii, I. Vidović-Bolt nie zamieszcza w swej pracy większych jednostek, jak: przysłowia, sfrazeologizowane powiedzenia, „skrzydlate słowa”. Monografia posiada zwartą, przemyślaną konstrukcję, składa się ze wstępu, dziewięciu rozdziałów poświęconych kolejnym zagadnieniom i szczegółowej analizie materiału, podzielonych dodatkowo na podrozdziały, wniosków końcowych oraz części leksykograficznej: słowników chorwackich i polskich frazeologizmów zoonimicznych omawianych w pracy. Pracę kończy bogaty spis bibliograficzny, zawierający 411 pozycji.

I. Vidović-Bolt rozpoczyna swą monografię od wprowadzenia czytelnika w skomplikowaną i zawiłą problematykę teoretycznych podstaw frazeologii w rozdziale I. Czyni to w sposób bardzo skondensowany, ale zwraca uwagę na najważniejsze kwestie: początki badań frazeologicznych w Polsce i Chorwacji, różnice terminologiczne, kluczowe definicje i sposoby pojmowania związku frazeologicznego w obu krajach. Kolejne rozdziały podzielić można na następujące kręgi zainteresowań: analiza strukturalna, fleksyjna (paradygmatyczna), syntaktyczna i semantyczna związków frazeologicznych. Rozdział III 
- Strukturna analiza hrvatskih i poljskih zoonimskih frazema zawiera podział na: fonetske riječi, sveze riječi i frazemske rečenice. Autorka podkreśla tu aspekt ilościowy, najmniej liczna jest pierwsza grupa, większość stanowią sveze riječi o typie czasownikowym. Na uwagę zasługuje fakt, że właściwie w całej pracy frazeologizmy polskie i chorwackie omawiane są łącznie, w pierwszej kolejności przykłady z języka chorwackiego.

Następnie analizowane jest zjawisko paradygmatyczności - rozdział IV, ze stwierdzeniem końcowym, że jest ona zazwyczaj częściowa. Rozdział V Sintaktička analiza hrvatskih i poljskih zoonimskih frazema wyodrębnia i omawia podstawowe grupy frazeologizmów ze względu na ich funkcję w zdaniu, tu szczegółowo opracowane są funkcje frazeologizmów rzeczownikowych, czasownikowych, przymiotnikowych, jak i tych w formie fraz. Rozdział VI poświęcony jest zjawisku wariantywności frazeologizmów, wśród omawianych przykładów występują wszystkie jej formy: fonetyczna, słowotwórcza, składniowa i leksykalna, z przewagą tej ostatniej.

Najwięcej miejsca w swej pracy poświęca Autorka szeroko rozumianym aspektom semantycznym frazeologizmów odzwierzęcych, co jest zgodne z nurtem wielu współcześnie powstających w Chorwacji opracowań dotyczących tematyki frazeologicznej. Semantycznej analizie poświęcony jest rozdział VII monografii Semantička analiza hrvatskih i poljskih zoonimskih frazema, dość obszerny (s. 41-85). Do semantyki nawiązuje też kolejny - rozdział VIII - Konceptna analiza hrvatskih i poljskih zoonimskih frazema (s. 87-138). Tak duża objętość tychże części pracy, sugeruje główny punkt ciężkości położony przez Autorkę - na semantyczną analizą omawianego materiału, która jest dokonana w sposób niezwykle szczegółowy i wnikliwy.

W rozdziale VII Autorka zwraca uwagę na szeroki wachlarz zjawisk i problemów natury semantycznej: motywację frazeologizmów, która może mieć charakter konkretny, asocjatywny lub nielogiczny (absurdalny) - gdy zwierzętom przypisujemy cechy dla nich nietypowe, często tworząc krzywdzące stereotypy. I. Vidović bardzo szczegółowo podchodzi do symboliki danych zwierząt domowych, sięgając w tym celu do źródeł i archetypów kulturowych, mitologicznych, biblijnych, związanych z tradycją danego obszaru i tu szukając eksplikacji znaczeń omawianych frazeologizmów. Uprzednio dokonuje Autorka ich klasyfikacji na kategorie: wpierw na ssaki i ptactwo domowe, które z kolei dzieli na mniejsze podgrupy zwierząt domowych.

Rozdział VIII jest przykładem podejścia kognitywnego do frazeologii, jako nośnika nie tyle znaczeń, ale pojęć, koncepcji, które wynikają ze struktury głębokiej, pewnych procesów myślowych, skojarzeń, wywołanych przez wypowiedzi językowe. Autorka dzieli omawiane formacje na dwie nadrzędne grupy: 
frazeologizmy odnoszące się do człowieka oraz nieodnoszące się do człowieka, a np. do jego otoczenia. Wykonała tu Autorka godną podziwu pracę, gdyż liczba pojęć, konotacji, które niosą ze sobą frazeologizmy zoonimiczne wyodrębnione w pracy, jest imponująca (sto kilkadziesiąt pojęć). Zauważa przy tym i podkreśla antropocentryzm frazeologizmów zwierzęcych, przeważająca większość z nich określa pojęcia odnoszące się do człowieka i to zazwyczaj o wydźwięku deprecjonującym. Jest to zgodne ze stanowiskiem polskich badaczy frazeologii zoonimicznej (m.in. Z. Kempf, K. Mosiołek-Kłosińska).

Ostatni rozdział analityczny poświęcony jest zjawisku ekwiwalencji omawianych frazeologizmów w obu językach. Wynika z niego konkluzja, że stopień całkowitej lub prawie całkowitej ekwiwalencji jest stosunkowo wysoki - od 45 do 63 par frazeologizmów.

Warto zwrócić uwagę na cenną i wartościową część leksykograficzną monografii, umieszczoną na końcu książki - słowniki zoonimicznych frazeologizmów chorwackich (323 przykłady, s. 151-167) i polskich (318 przykładów, s. 169-184). Wobec braku większego dwujęzycznego słownika frazeologizmów polskich i chorwackich, wykazy te stanowią, choć w dziedzinie frazeologii zoonimicznej, nieocenioną pomoc w pracach porównawczo-językowych czy przekładowych. Zwłaszcza że przygotowane są zgodnie z zasadami obowiązującymi przy tworzeniu haseł słownikowych.

Podsumowując, należy stwierdzić, iż monografia I. Vidović-Bolt jest bardzo ważną pozycją w dziedzinie badań kontrastywnych polskiej i chorwackiej frazeologii, sprawia wrażenie „zapowiedzi” dalszych rozważań, być może dotyczących innych obszarów i kategorii znaczeniowych. Byłoby to zjawiskiem wielce pożądanym, gdyż w tej dziedzinie nie ma zbyt wielu zwartych, obszerniejszych opracowań. Na pochwałę zasługuje przede wszystkim, rzetelność naukowa, dogłębna, wieloaspektowa analiza językoznawcza, ale także przystępność odbioru, komunikatywność języka, odwoływanie się do symboliki kulturowej, społecznej, tradycji, legend przy omawianiu znaczeń w części poświęconej semantyce, co ogółem sprawia, że po monografię sięgnąć może każdy czytelnik zainteresowany frazeologią, nie tylko posiadający przygotowanie językoznawcze. 